\title{
PENGEMBANGAN BAHAN AJAR BERBANTUAN AMRITA OLABS PADA MATERI GELOMBANG BUNYI
}

\author{
Arsel Bungkuran, Heindrich Taunaumang, Alfrits Komansilan \\ Fakultas Matematika dan Ilmu Pengetahuan Alam, Universitas Negeri Manado \\ email: arselbungkuran98@gmail.com
}

\begin{abstract}
ABSTRAK
Penelitian ini dilaksanakan dengan tujuan untuk menghasilkan produk bahan ajar berbantuan Amrita olabs pada materi gelombang bunyi untuk SMA kelas XI khusus jurusan IPA. Penelitian ini dilaksanakan pada kelas XI IPA 2 SMA Negeri 1 Tondano yang berjumlah 33 orang peserta didik. Pada penelitian ini hanya 22 orang dari 33 orang peserta didik yang ikut serta dalam penelitian. Amrita olabs merupakan inovasi terbaru untuk simulasi-simulasi percobaan di laboratorium virtual. Amrita olabs tidak hanya dapat digunakan di labtop, tetapi bisa juga digunakan di HP android/iphone. Metode penelitian yang digunakan adalah metode Research and Development (R\&D) dengan model 4D. Pengambilan data dilakukan dengan cara mengvalidasi perangkat pembelajaran berupa bahan ajar berbantuan Amrita olabs menggunakan angket. Berdasarkan hasil analisis respon peserta didik setelah menggunakan bahan ajar berbantuan Amrita olabs diperoleh bahwa bahan ajar berbantuan Amrita olabs dikatakan baik sesuai dengan rata-rata presentase respon peserta didik baik. Efektivitas dari penggunan bahan ajar berbantuan Amrita olabs yang dilihat berdasarkan nilai gain diperoleh $54,7 \%$ dengan kategori sedang. Analisi hasil penelitian ini menunjukkan bahwa bahan ajar berbantuan Amrita olabs layak digunakan dalam pembelajaran fisika dan mampu meningkatkan kemampuan fisika peserta didik.
\end{abstract}

Kata kunci : Bahan ajar berbantuan Amrita olabs, Peningkatan kemampuan fisika peserta didik

\begin{abstract}
The study was carried out with the goal of producing teaching products with the aid of Amrita olabs on sound wave materials for the 11th grade in physics. The study was conducted at 11th SMA Negeri 1 Tondano science class, which held 33 students. In this study only 22 of the 33 trainees participated in the study. Amrita olabs is the latest innovation for simulations of virtual laboratory experiments. Amrita olabs can be used not only in labtop but also in android/iphone phones. The research method used was research and development $(R \& D)$ with model $4 D$. Data retrieval involves validating the learning tools of Amrita olabs using angkets. Based on the results of improved response analysis after using the teaching material Amrita olabs is obtained that the teaching material with Amrita olabs is said to be good according to the avarage percentage of learners' responses. The effectiveness of using an Amrita olabs based on gain value is gained $54,7 \%$ by medium category. Analysis of the results of the study suggests that the teaching material provided by Amrita olabs is worthy of use in the study of physics and is capable of improving the physical abilities of learners.
\end{abstract}

Keywords : Teaching material aid Amrita olabs, Improved cognitive physics 


\section{PENDAHULUAN}

Revolusi industri merupakan sejarah perkembangan terpenting dalam kehidupan manusia selama tiga abad terakhir yang sifatnya berkelanjutan dalam hal membangun kehidupan dunia dizaman moderen ini (Stearns, 2013). Istilah revolusi industri sudah lama dipakai untuk menjelaskan perubahan pada aspek general di bidang industri yang saling berkaitan misalnya teknologi dasar yang digunakan pada pabrik-pabrik, mesin-mesin yang dibangun dari teknologi tersebut, serta rutinitas buruh yang bekerja. Revolusi industri dibagi ke dalam beberapa generasi antara lain salah satunya revolusi industri 4.0 atau yang dikenal industri 4.0. Hal ini mengakibatkan terjadi perubahan yang sangat signifikan seperti perubahan sosial, tata laksana organisasi industri, ekonomi mikro, dan teknologi yang dipakai. Laju perkembangan yang terjadi pada era industri ini (industri 4.0) sangat mempengaruhi pola gaya hidup masyarakat moderen (Wiyono, 2019).

Pendidikan di era industri 4.0 sebagai cara untuak melengkapi fenomena integrasi digital dalam kehidupan sehari-hari yang dimana manusia dan mesin saling berinteraksi untuk memecahkan masalah dan menemukan teori inovasi baru (Wiyono, 2019). Pada pendidikan era industri 4.0 ini, akses informasi tidak terbatas lagi dengan ruang dan waktu serta proses belajar mengajar sudah menjadi dinamis. Pada masa depan, pendidikan era industri 4.0 bisa mengubah pemanfaatan informasi dengan cara yang praktis dan berbasis digital. Dalam mengatasi kebutuhan revolusi industri 4.0 untuk bidang pendidikan, lembaga-lembaga pendidikan harus terus berinovatif untuk meningkatkan proses belajar mengajar.

Pemerintah telah banyak melakukan upaya-upaya untuk meningkatkan kualitas pendidikan. Salah satu bagian upaya yang dilakakukan oleh pemerintah adalah melakukan penyempurnaan kurikulum 2013 dengan tujuannya menyiapkan peserta didik agar memiliki kemampuan hidup sebagai pribadi dan warga negara yang beriman, produktif, inovatif, dan mampu berkontribusi dalam berkehidupan bermasyarakat, berbangsa, bernegara dan peradaban dunia (Perkemendikbud No 70 Tahun 2013). Tuntutan pada kurikulum 2013 antara lain pembelajaran berpusat pada peserta didik dengan menggunakan pendekatan scientific.
Dengan kemajuan teknologi pada era industri 4.0 ini, media-media pembelajaran dan sumber belajar terus mengalami inovasi, sehingga ini menantang peserta didik agar bisa belajar secara mandiri dan mampu menyelesaikan masalah yang sifatnya abstrak dengan pendekatan ilmiah. Dalam hal ini (di era industri 4.0), peran guru hanya sebagai fasilitator, motivator, dan salah satu alternatif sumber belajar. Tugas guru mendesain bahan ajar yang sesuai dengan tuntutan kurikulum 2013 yang bisa membelajarkan peserta didik sehingga dapat menguasai kompetensi yang sudah ditetapkan. Artinya pengembangan bahan ajar harus memperhatikan tuntutan kurikulum.

Pada saat ini virus corona sedang melanda dunia termasuk Indonesi, sehingga berdampak disemua bidang salah satunya bidang pendidikan. Kementrian pendidikan dan Kebudayaan (Kemendikbud) mengambil tindakan untuk kegiatan pembelajaran dilaksanakan secara jarak jauh berupa daring (dalam jaringan) atau luring (luar jaringan) sesuai dengan pembagian zona wilayah untuk semua sekolah di Indonesi. Pembelajaran daring bertujuan untuk memenuhi standar pendidikan dengan pemanfaatan teknologi informasi dengan menggunakan perangkat komputer atau gadget yang saling terhubung antara peserta didik dan guru sehingga melalui pemanfaatan teknologi proses belajar mengajar tetap terlaksana dengan baik. Pembelajaran daring adalah sistem belajar yang terbuka dan tersebar dengan menggunakan perangkat pedagogi (alat bantu pendidikan) yang dimungkinkan melalui internet dan teknologi berbasis jaringan untuk memfasilitasi pembentukan proses belajar dan pengetahuan melalui aksi dan iteraksi yang berarti (Dabbagh dan Ritland dalam Arnesi dan Hamid, 2015). Hal ini berkaitan dengan tantangan peserta didik dalam menghadapi pendidikan di era industri 4.0 yang mengharuskan peserta didik dapat mengembangkan dirinya secara mandiri.

Sains merupakan bagian dari ilmu pengetahuan terbentuk dari interrelasi antara sikap dan proses sains, penyelidikan fenomena alam, dan produk keilmuan (Carin dalam Tumiwa, 2020). Melalui pendidikan sains, diharapkan masyarakat dapat memahami konsep sains dan menerapkannya dalam kehidupan sehari-hari untuk memecahkan 
masalah (Mariana \& Praginda dalam Tumiwa, 2020). Fisika merupakan salah satu cabang dari sains. Fisika adalah cabang ilmu sains yang tidak hanya terbatas pada pengetahuan konsep dan persamaan matematisnya, namun fisika harus mencakup pada pemahaman fisis dan aplikasinya dalam kehidupan sehari-hari. Dalam bidang sains sangat diperlukan pemahaman tentang literasi sains.

Literasi sains berarti kemampuan memahami, berpikir dan mengaplikasikan konsep dan prespektif sains dalam kejadian (Abidin, 2014). Literasi sains sangat membutuhkan pengetahuan tentang prosedur dan praktik bukan hanya pada pengetahuan konsep. Chiapetta dalam Tumiwa (2020) mengungkapkan bahwa ada empat aspek literasi sains yakni sains sebagai batang tubuh pengetahuan, sains sebagai cara untuk berpikir, sains sebagai cara untuk menyelidiki, dan interaksi antara sains, teknologi, dan masyarakat. Pengajaran dalam pembelajaran fisika diharapkan untuk mencakup pada empat aspek literasi sains, tetapi ditemukan kebanyakan dalam pembelajaran fisika hanya terfokus pada pemahaman konsep untuk kegiatan menyelidiki (kegiatan praktikum) kadang dilaksanakan. Apalagi pada pembelajaran jarak jauh ini ditemukan bahwa pelaksanaan kegiatan praktikum kadang atau bahkan tidak dilaksanakan. Bahan ajar yang di dalamnya berisikan kegiatan percobaan sangat dibutuhkan agar dapat memacu minat belajar mandiri peserta didik.

Amrita olabs merupakan software untuk melaksanakan percoban online di bidang sains. Olabs merupakan laboratorium virtual yang dikembangkan untuk menyediakan simulasisimulai percobaan di bidang sains yang bisa digunakan oleh guru jika tidak tersedianya peralatan nyata. Olabs ini dapat diakses menggunakan labtop dan juga HP secara gratis. Olabs ini merupakan perkembangan teknologi di bidang pendidikan yang diharapkan dapat membantu guru dalam memenuhi kebutuhan keterlaksanaan praktikum di sekolah. Penggunaan olabs ini sangat efektiv dan efisien, dan dapat meminimalisir penggunaan waktu yang sangat banyak pada pelaksanaan praktikum.

Berdasarkan hasil studi pustaka dan analisis bahan ajar, diketahui bahwa pada pelaksanaan pembelajaran daring ini, peserta didik tidak diberikan bahan ajar untuk membantu kebutuhan materi dan tidak dilaksanakan kegiatan praktikum. Oleh karena itu, penelitian kali ini bertujuan untuk menghasilkan bahan ajar berbantuan Amrita olabs pada materi gelombang bunyi.

\section{METODE PENELITIAN}

Penelitian ini adalah penelitian pengembangan yang dilaksanakan di SMA Negeri 1 Tondano. Data penelitian diambil pada semester genap Tahun Pelajaran 2020/2021. Subyek dari penelitian ini adalah pengembangan bahan ajar berbantuan Amrita olabs pada materi gelombang bunyi yang diuji cobakan kepada peserta didik kelas XI IPA 2 SMA Negeri 1 Tondano yang berjumlah 22 orang peserta didik. Penelitian ini menggunakan metode penelitian dan pengembangan $\mathrm{R} \& \mathrm{D}$ (Research and Development). Metode penelitian dan pengembangan (Sugiyono, 2017) adalah metode penelitian yang digunakan untuk menghasilkan produk tertentu, dan menguji keefektifan produk tersebut. Produk yang dihasilkan dalam penelitian ini adalah pengembangan bahan ajar berbantuan Amrita Olabs pada materi gelombang bunyi. Peneliti menggunakan metode 4-D (Four-D Model) yang dikembangkan oleh S. Thiagarajan (dalam Yohan, 2020) yang meliputi tahap define (pendefinisian), design (perencanaan), develop (pengembangan), dan disseminate (penyebaran). Penelitian kali ini hanya melakukan tiga tahap, yaitu pertama tahap define (pendefinisian), kedua tahap design (perencanaan), ketiga develop (pengembangan) merupakan tahap untuk mengvalidasi perangkat demi menghasilkan perangkat yang layak digunakan, dan untuk tahap disseminate (penyebaran) tidak dilaksanakan oleh peneliti karena perangkat yang dikembangkan hanya diterapkan pada sekolah uji coba belum disebarkan ke sekolahsekolah lain.

Implementasi perangkat pembelajaran ini menggunakan pretest-posttest group design pada satu kelompok subyek (Tucman dalam Sumarauw, dkk., 2017). Rancangan ini hanya diterapkan pada satu kelompok (kelas eksperimen) tanpa menggunakan kelompok pembanding (kelas kontrol). Rumusan rancangannya sebagai berikut.

Keterangan:

$$
\mathrm{Q}_{1} \times \mathrm{Q}_{2}
$$


$\mathrm{Q}_{1}=$ Pengujian awal untuk mengetahui penguasaan aspek pengetahuan pada peserta didik sebelum pemberian perlakuan

$\times=$ Pemberian perlakuan dengan menggunakan bahan ajar berbantuan Amrita olabs

$\mathrm{Q}_{2}=$ Pengujian akhir untuk mengetahui penguasaan aspek pengetahuan pada peserta didik setelah pemberian perlakuan

Dari rancangan di atas, pelaksanaan eksperimen diawali pemberian pretest untuk mengetahui kemampuan awal peserta didik terhadap materi yang akan diajarkan. Kemudian diberikan perlakuan kepada kelompok kelas eksperimen ini, setelah selesai diberikan perlakuan, peserta didik diberikan posttest untuk mengukur kemampuan akhir peserta didik.

Teknik pengumpulan data pada penelitian ini adalah sebagai berikut (1) Data validasi instrumen perangkat pembelajaran dan instrumen pengambilan data didapatkan melalui dosen ahli materi fisika FMIPA UNIMA dan guru fisika SMA;(2) Data validasi bahan ajar fisika berbantuan Amrita olabs yang divalidasi oleh dosen Jurusan Pendidikan Fisika FMIPA UNIMA dan guru fisika, serta tingkat reliabilitas bahan ajar berdasarkan data respon peserta didik;(3) Data pretest-posttest untuk mengetahui peningkatan kemampuan peserta didik setelah menggunakan bahan ajar berbantuan Amrita olabs; dan (4) Dokumentasi data hasil pengisian instrumen oleh peserta didik dan foto selama peserta didik menggunakan bahan ajar fisika berbantuan Amrita olabs. Teknik analisis data yang digunakan pada penelitian ini yaitu teknik analisis kualitatif digunakan untuk mendeskripsikan hasil saran dosen validasi, respon pengguna, dan catatan dokumentasi saat diimplementasikan dan teknik analisis kuantitatif digunakan untuk mendeskripsikan kualitas bahan ajar berbantuan Amrita olabs

berdasarkan penilaian dosen ahli materi maupun praktisi serta mendeskripsikan kemampuan peserta didik setelah menggunakan bahan ajar berbantuan Amrita olabs.

\section{HASIL DAN PEMBAHASAN}

Jenis dari penelitian ini adalah penelitian pengembangan dengan model yang diterapkan yaitu model 4D yang terdiri dari design, define, develop, dan dissiminate. Penelitian ini dilaksanakan di SMA Negeri 1 Tondano, Kabupaten Minahasa, Sulawesi Utara dengan subjek dari penelitian ini adalah peserta didik kelas XI IPA 2 yang berjumlah 33 orang. Dari jumlah peserta didik 33 orang yang ikut dalam pelaksanaan penelitian hanya 22 orang peserta didik. Tujuan dari penelitian ini adalah: (1) Mengetahui tingkat kelayakan dari bahan ajar berbantuan Amrita olabs; (2) Mengetahui peningkatan kemampuan fisika dari peserta didik menggunakan bahan ajar berbantuan Amrita olabs. Penelitian ini diawali dengan membuat perangkat pembelajaran yaitu RPP, bahan ajar berbantuan Amrita olabs, dan instrumen tes. Kemudian perangkat yang sudah dikembangkan ini divalidasi oleh validator yang sudah berkompeten dibidangnya agar menghasilkan penilaian terhadap perangkat yang dikembangkan. Setelah dinilai perangkat oleh validator, kemudian hasil penilaian dari perangkat ini dianalisi untuk mendapatkan hasil apakah perangkat yang dikembangkan layak/tidak layak dipakai dalam pembelajaran.

Validasi perangkat perangkat pembelajaran

Perangkat pembelajaran yang divalidasi pada penelitian kali ini yaitu: 1) RPP; 2) Bahan ajar berbantuan Amrita olabs; dan 3) Instrumen tes. Validitas dilakukan dengan tujuan untuk melihat kualitas dari perangkat yang dikembangkan.

Validasi RPP dilaksanakan melalui uji validasi yang dilakukan oleh ahli (pakar) dan praktisi.

Tabel 1 Hasil Analisis Kelayakan RPP

\begin{tabular}{|c|c|c|c|c|}
\hline \multirow[b]{2}{*}{ No. } & \multirow[b]{2}{*}{ Aspek } & \multicolumn{3}{|c|}{ Validator } \\
\hline & & $\begin{array}{l}\text { Dosen } \\
1\end{array}$ & $\begin{array}{l}\text { Dosen } \\
2\end{array}$ & Guru \\
\hline 1 & $\begin{array}{l}\text { Perumusan tujuan } \\
\text { pembelajaran }\end{array}$ & 5 & 5 & 5 \\
\hline 2 & $\begin{array}{l}\text { Pemilihan materi } \\
\text { ajar }\end{array}$ & 5 & 5 & 5 \\
\hline 3 & $\begin{array}{l}\text { Pemilihan metode } \\
\text { pembelajaran }\end{array}$ & 4 & 5 & 4 \\
\hline 4 & $\begin{array}{l}\text { Pemilihan sumber } \\
\text { belajar }\end{array}$ & 5 & 4 & 4 \\
\hline 5 & $\begin{array}{l}\text { Kegiatan } \\
\text { pembelajaran }\end{array}$ & 5 & 4 & 5 \\
\hline \multicolumn{2}{|c|}{ Rata-rata } & 4,8 & 4,6 & 4,6 \\
\hline \multicolumn{5}{|c|}{ Nilai Rata-Rata $(\overline{\mathrm{X}})=4,66$} \\
\hline \multicolumn{2}{|c|}{ Kategori } & \multicolumn{3}{|c|}{ Sangat Baik } \\
\hline
\end{tabular}


Berdasarkan hasil analisis terhadap RPP yang sudah divalidas oleh validator yang terlihat pada Tabel 1, RPP memiliki rata-rata penilaian validator sebesar 4,66 dengan kategori sangat baik. Sukarjo dalam Timiwa (2020) mengatakan bahwa kategori sangat baik jika rentang rata-rata penilaian $>4,26$ sehingga RPP dinyatakan layak untuk digunakan dalam penelitian.

Hasil analisis terhadap bahan ajar berbantuan Amrita olabs yang sudah divalidas oleh validator, bahan ajar ini memiliki rata-rata penilaian validator sebesar 3,79 dengan kategori baik. Sukarjo (2006) mengatakan bahwa kategoribaik jika rentang rata-rata penilaian 3,42 $<X \leq 4,26$ sehingga bahan ajar ini dinyatakan layak untuk digunakan dalam penelitian. Hasil analisis terhadap butri soal pretest-posttest yang sudah divalidas oleh validator, butri soal pretest-posttest memiliki rata-rata penilaian validator sebesar 4,6 dengan kategori sangat baik. Sukarjo dalam Timiwa (2020) mengatakan bahwa kategori sangat baik jika rentang rata-rata penilaian $>4,26$ sehingga butri soal pretest-posttest dinyatakan layak untuk digunakan dalam penelitian.

\section{Kelayakan bahan ajar berbantuan Amrita olabs}

1. Kelayakan bahan ajar berbantuan Amrita olabs oleh validator ahli dan praktisi

Kelayakan untuk bahan ajar berbantuan Amrita olabs ini ditinjau dari hasil penilaian validator yaitu dosen dan guru mata pelajaran fisika. Jadi, kedua valiadator ini memberikan penilai terhadap bahan ajar, hasil dari penilaian validator ini akan menentukan bahan ajar berbantuan Amrita olabs ini layak/tidak layak digunakan pada pembelajaran fisika. Penilaian dan saran oleh validator ini akan digunakan sebagai dasar merevisi bahan ajar. Validasi ini dilakukan oleh pakar yang berkompeten dibidang ini. Berdasarkan penilaian yang diberikan oleh validator dan hasil analisi dari penilaian validator didapatkan bahwa bahan ajar berbantuan Amrita olabs layak digunakan pada pembelajaran fisika karena berdasarkan hasil analisis penilaia validator, bahan ajar berbantuan Amrita olabs berkategori baik dengan nilai rata-rata penilaian sebesar 3,79. Dalam penilaian ini ada beberapa aspek yang dinilai saat validasi oleh validator yang merujuk pada hasil penelitian dari Mawarni dalam Tumiwa (2020) yaitu isi media, aspek bahasa dan gambar, aspek penyajian, dan aspek kegrafikan. Keempat aspek tersebut untuk secara keseluruhan terpenuhi untuk bisa dikatakan bahan ajar layak digunakan, namau bukan berati bahan ajar ini sudah sempurna karena untuk isi modul masih ada informasi yang belum dituangkan pada penulisan bahan ajara.

2. Keefektifan bahan ajar berbantuan Amrita olabs terhadap kemampuan fisika peserta didik

Pada kelas eksperimen ini, peneliti memberikan perlakukan dengan memberikan peserta didik bahan ajar berbantuan Amirita olabs pada materi gelombang bunyi. Berdasarkan hasil analisis respon peserta didik terhadap bahan ajar berbantuan Amrita olabs adalah baik berdasarkan persentase rata-rata respon peserta didik pada bahan ajar adalah baik. Hasil respon peserta didik yang hanya merespon bahwa bahan ajara ini baik dikarenakan di dalam angket respon peserta didik terhadap bahan ajar terdapat beberapa pernyataan negatif akan tetapi tidak semua peserta didik mengerti pernyataan positif dan negatif. Sehingga penyataan ini mempengaruhi hasil penilaian terhadap bahan ajar berbantuan Amrita olabs.

Efektivitas dari penggunaan bahan ajar berbantuan Amrita olabs pada kelas eksperimen bisa kita lihat pada hasil nila $N$ gainnya. Berdasarkan hasil analisis nilai gainnya diperoleh nilai gainnya sebesar 0,547 atau $54,7 \%$ dengan kategori sedang. Sehingga berdasarkan hasil nilai gainnya bahan ajar berbantuan Amrita olabs cukup efektif digunakan pada pembelajaran fisika untuk membantu memenuhi sumber belajar peserta didik.

\section{Peningkatan fisika peserta didik dengan menggunakan bahan ajar berbantuan Amrita olab}

Berdasarkan hasil posttest dari peserta didik untuk kemampuan fisika untuk aspek kognitif (pengetahuan) mereka meningkat seiring diberikan perlakuan dengan bahan ajar berbantua Amrita olabs. Gambar 1 menampilkan hasil pretest-posttest peserta didik. 


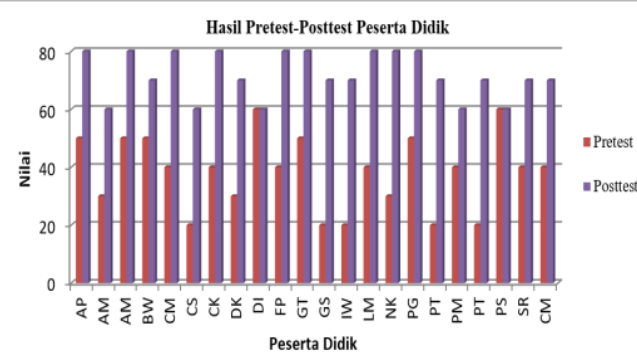

Gambar 1 Grafik peningkatan kemampuan fisika peserta didik berdasarkan hasil pretest-posttest

Berdasarkan gambar 1, terlihat perbedaan yang cukup signifikan setelah peserta didik diberikan perlakuan dengan bahan ajar berbantuan Amrita olabs walaupun masih ada nilai yang diperoleh peserta didik belum sampai pada standar ketuntasan. Namun, peningkatan yang dialami oleh peserta didik dengan menggunakan bahan ajar berbantuan Amrita olabs cukup signifikan. Sehingga dapat dikatakan adanya peningkatan kemampuan fisika terhadap peserta didik. Misalnya bisa kita lihat pada peserta didik AP dan AM. Pada AP sebelum diberikan perlakukan (hasil pretest) memperoleh nilai 50, sedangkan seteleh diberikan perlakukan diberikan bahan ajar berbantuan Amrita olabs (hasil posttets) memperoleh nilai 80. Kemudia sama hal juga dengan AM, sebelum diberikan perlakukan dengan bahan ajar berbantuan Amrita olabs (hasil pretest) memperoleh nilai 30, ketika diberikan perlakuan dengan bahan ajar berbantuan Amrita olabs (hasil posttest) memperoleh nilai 60. Disini memang terlihat untuk peserta didik AM dengan nilai 60 dinyatakan belum mencapai nilai ketuntasan. Dari kedua peserta didik ini, dapat dilihat bahwa ada peningkatan kemampuan fisika dari peserta didik dilihat berdasarkan perbedaan nilai yang diperoleh pada pretest-posttest dimana ada peningkatan pada perolehan nilai dari kedua peserta didik. Walaupun pada peserta didik AM nilai yang diperoleh belum mencapai nilai ketuntasan, namu dari peserta didik ini ada peningkatan terhadap nilai yang diperoleh. Maka bida dinyatakan bahwa bahan ajar berbantuan Amrita olabs sangat membantu dalam peningkatan kemampuan fisika peserta didik pada aspek kognitifnya.

\section{KESIMPULAN}

Berdasarkan hasil penelitian dan pembahasan, peneliti dapat menyimpulkan bahwa bahan ajar berbantuan Amritas Olabs layak digunakan pada pembelajaran fisika pada materi gelombang bunyi dan efektif meningkatkan kemampuan fisika peserta didik yang dimana ada perbedaan peningkatan kemampuan pada peserta didik kelas XI IPA 2 SMA Negeri 1 Tondano yang signifikan setekah diberikan bahan ajar berbantuan Amrita olabs pada materi gelombang bunyi.

\section{REFERENSI}

Abdullah, M. (2006). Fisika SMA/MA Untuk Kelas XI Semester I. Jakarta: Erlangga.

Haridas, M. (2014). Blending Concept Maps with online Labs (Olabs): Case Study with Biological Science.

Hake, R. R. (1999). Analyzing Change/Gain Scores.Diakses pada tanggal 22 April 2020,

dari:http://www.physics.idiana.edu/ sdi/ AnalyzingChange-Gain.pdf

IE Nurrokhmah, W. S. (2013). Pengaruh Penerapan Virtual Lab Berbasis Inkuiri Terhadap Hasil Belajar. Chemistry in Education.

Indarti, A. P. (2016). Buku Siswa Fisika Peminatan Matematika Dan Ilmu Pengetahuan Alam Untuk SMA/MA XI. Surakarta: CV Mediatama.

Lengkey, S. (2014). Pengembangan Prototipe Perangkat Pembelajaran Animasi Materi Hukum Gravitasi Newton (Skripsi). Tondano: UNIMA.

Kanginan, M. (2017). Fisika Untuk SMA/MA Kelas XI. Cimahi: Erlangga.

Kemendikbud. (2017). Peringkat dan Capaian PISA Indonesia Meengalami Peningkatan. Artikel Kemendikbud Biro Komunikasi dan Layanan Masyarakat Kementrian Pendidikan dan Kebudayaan 06 Desember 2017.

(Online:http://www.kemendikbud.go.id/m ain/blog/2016/12/peringkat-dan-capaianpisa-indonesia-mengalami-peningkatan)

Wiyono, K., Zakiyah, S. (2019). Pendidikan Fisika Pada Era Revolusi $4.0 \quad \mathrm{Di}$ Indonesia. Seminar Nasional Pendidikan, $1-14$.

Kusdiastuti, M. (2016). Pengaruh Model Pembelajaran Inkuiri Berbantuan Laboratorium Virtual terhadap Penguasaan Konsep Fisika Peserta Didik. Jurnal Pendidikan Fisika dan Teknologi, 116-122. 
Majid, A. (2013). Strategi Pembelajaran. Bandung: PT Remaja Bosday.

Maulida, S. I. (2019). Pengembangan Modul Fisika Gelombang Bunyi Berbasis REACT Untuk Kelas XI IPA . Jember: Universitas Jember.

Mundilarto. (2010). Penilaian Hasil Belajar Fisika. Pusat Pengembangan Sains: Universitas Yogyakarta.

Prema Nedungadi, P. M. (2015). Inquiry Based Learning Pedagogy for Chemistry Practical Experiments Using OLabs. Amrita Center for Research in Advanced Technologies for Education.

Prema Nedungadi, R. R. (2013). Enhanced STEM Learning with Online Labs: Empirical Study Comparing Physical Labs, Tablets and Desktop. Amrita university.

Roida Pakpahan, y. F. (2020). Analisa Pemanfaatan Teknologi Informasi Dalam Pembelajaran Jarak Jauh Di Tengah Pandemi Virus Corona. Journal of Information Sysem, Applied, Management, Accounting and Research.

Saputra, T.B.R., dkk. (2017). Pengembangan Pembelajaran Inkuiri Berbantuan PhET. Journal of Science Education And Practice, 1, 20-31.

Stearns, P. (2013). The Industrial Revolution in World History (4th ed.). USA: Westview Press.

Sudiarman, W. S. (2015). Pengembangan Perangkat Pembelajaran Fisika Berbasis Inkuiri Terbimbing Untuk Melatihkan Ketrampilan Proses Sains dan Meningkatkan Hasil Belajar pada Topik Suhu dan Perubahannya (Skripsi). Pendidikan Sains Pascasarjana Universitas Negeri Surabaya, 658-671.

Sugiyono. (2012). Metode Penelitian Pendidikan (Pedekatan Kuantitatif, Kualitatif, dan $R \& D)$. Bandung: Alfabeta.

Sukarjo. (2006). Desain Pesrta Didik: Evaluasi Peserta Didik. Hand-Out Perkuliahan: PPS Universitas Negeri Yogyakarta.

Sumarauw, J. M. (2017). Pengembangan Perangkat Pembelajaran Berbasis Inkuiri Terbimbing Berbantuan Simulasi PhET Dalam Pembelajaran IPA. Jurnal Penelitian Pendidikan.

Tumiwa, M. N. (2020). Pengembangan Bahan Ajar Berbasis Literasi Sains Pada Materi Momentum dan Impuls(Skripsi). Tondano:
UNIMA.

Yohan, J. (2020). Pengembangan Panduan Praktikum Generator Satu Fase Dan Tiga Fase Berbasis Inkuiri Terbimbing Dengan Metode Mentoring(Skripsi) . Tondano: UNIMA. 